\title{
Developing Kamishibai and Hologram Multimedia for Environmental Education at Elementary School
}

\author{
Asep Herry Hernawan ${ }^{*}, 1$, Deni Darmawan ${ }^{1}$, Asyifa Imanda Septiana ${ }^{2}$, Idriyani Rachman ${ }^{3}$, Yayoi Kodama ${ }^{4}$ \\ ${ }^{1}$ Curriculum and Educational Technology Department, Faculty of Education, Universitas Pendidikan Indonesia, 15606, Indonesia
}

${ }^{2}$ Software Engineering Department, Universitas Pendidikan Indonesia, 15606, Indonesia

${ }^{3}$ Social Studies Department, Faculty of Humanities, The University of Kitakyushu, 800-0001, Japan

${ }^{4}$ Graduate Programs in Environmental Systems, Faculty of Environmental Science, The University of Kitakyushu, 800-0001, Japan

\begin{tabular}{l} 
A R T I C L E I N F O \\
\hline Article history: \\
Received: 20 December, 2020 \\
Accepted: 26 February, 2021 \\
Online: 20 March, 2021 \\
\hline
\end{tabular}

Keywords:

Environmental Education

Kamishibai

Hologram

Educational Multimedia

Human-Computer Interface

\begin{abstract}
A B S T R A C T
A Japanese method in teaching at classroom show good result by implementing Kamishibai. On the other hand, technology is inseparable from daily life. Computer-based learning media innovations are fast and diverse, ranging from $2 D$ animation to $3 D$ environments. The hologram is one example of $3 D$ object visualization to deliver the learning material. Based on Kamishibai's opportunity and hologram multimedia utilization to enhance the environmental education teaching activity, research about the adaptation of $3 D$ pyramid hologram for teaching environmental education in elementary school is proposed. Firstly, the kamishibai model for teaching environmental education from Japan is explored and modified to fit Indonesia's condition. The kamishibai and hologram multimedia utilization in teaching environmental education has been experimented with in class. The results of learning kamishibai and multimedia holograms show that students will improve their abilities in environmental problems. The students lead the literacy and caring attitudes were following their level of knowledge and skills as well as their attitudes about caring about disposing of garbage in its place, learning to clean sewerage at school, learning to farm in the yard of schools, and understand how plants exist in school gardens.
\end{abstract}

\section{Introduction}

Our earth's condition is continuously degrading. Many environmental-related problems start with pollution, waste, climate change, global warming, and civilization. Those problems are not only faced by Indonesia but all of the countries in the world. Environmental education for a sustainable living must be applied to start from an early age. Every school must invite and introduce students to understand the natural conditions and natural problems at this time.

Environmental education plays an essential role in preserving and improving the world's environment in realizing a sustainable life. A necessary goal of environmental education is to make individuals and communities understand the complex nature of nature and the built environment resulting from the interaction of their biological, physical, social, economic, and cultural aspects, and acquire the knowledge, values, attitudes, and practical skills to participate in a way that is responsible and effective in

"Corresponding Author: Asep Herry Hernawan. Email: asepherry@upi.edu anticipating and solving environmental problems, and in managing environmental quality. To increase students' awareness to be more sensitive to current natural conditions for a sustainable society, environmental education should include the affective aspects of behavior, values, and commitment. Therefore, in the learning process, the teacher needs to have methods to clarify and internalize values.

Japan is one of the best examples in the world to learn about environmental education. There was a city named Kitakyushu that once was severely polluted, as in the 1960's air pollution in the Kitakyushu area was the nation's worst and had a sea contaminated with industrial waste. The municipal government worked very hard together with businesses and citizens to solve the problems. To create a low-carbon society, the city was selected in July 2008 to be an Eco-Model City. One of the steps to make it an Eco-Model City is hidden behind how environmental education is done there. 
Learning from Japan's school curriculum on environmental education has a similar concept to the Indonesian curriculum. Environmental education is also integrated with other subjects, but they have a different method to teach. Nagoya, a historical city in the development of knowledge, has an experiment about Kamishibai in teaching environmental education and shows an excellent result at the effectiveness [1]. The same excellent product comes from Miyagi University in collaboration with JICA and Japanese Overseas Cooperation Volunteers (JOCV), while they used kamishibai as a learning medium in developing countries.

Kamishibai is a traditional form of Japanese storytelling that uses large color pictures to accompany a dramatic narration [2]. Kamishibai consists of stories in images with multiple uses. It is arranged based on a plot and designed to enhance imagination by enriching developed words and ideas. The pictures can be either selected from readily available stocks or self-drawn. Kamishibai has enjoyed a renaissance because teachers and librarians have revived this Japanese art of illustration telling for their children's benefit [3]. Based on previous research, Kamishibai can motivate the student, create a joyful environment, improve student ability, and be involved in the context quickly [4]. It opens opportunities for teachers to make critical choices across various possibilities that range from extreme top-down control [5]. Therefore, the potential of kamishibai usage for teaching environmental education in Indonesia should be explored.

On the other hand, technology is inseparable from daily life. Essentially technological advances will go according to scientific progress. Besides, technology can also make it easier for students to understand the learning material delivered and bring benefits to the advancement of the human race civilization [6]. Computerbased learning media innovations are fast and diverse, ranging from 2-dimensional (2D) animation to using Augmented Reality (AR) or Virtual Reality (VR) technology in 3-dimensional (3D) environments. With 3D object visualization, learning material becomes easier to understand and intuitive [7]. The hologram is one example of $3 \mathrm{D}$ object visualization to deliver the learning material. Many methods can be used to create holographic objects. One of the most frequently used is the pepper ghost method [8]. Using the pepper ghost hologram method, 3D virtual objects can be displayed directly in the real world without the need to use unique cameras or glasses such as VR or AR. Unlike AR or VR that limit the user from seeing the $3 \mathrm{D}$ object image and isolates them from their environment, hologram technology can be used by more than one people at the same time and enable its user to do the social interaction. Based on the opportunity of Kamishibai and hologram utilization as a media to enhance the environmental education teaching activity, a research about the adaptation of kamishibai and 3D pyramid hologram for teaching environmental education in elementary school is proposed.

Firstly, the kamishibai model for teaching environmental education from Japan is explored and modified to fit Indonesia's condition. The content of hologram multimedia is also designed to meet the needs of teaching environmental education. Then, the kamishibai and hologram multimedia utilization in teaching ecological knowledge have experimented in class. The experiment learns about the effectiveness of kamishibai, hologram multimedia, and the combination of both. The data is collected from questionnaires, interviews, post-tests, and pre-tests gathered during the class experiment. The research purpose: (a) Explore hologram multimedia's potential as an innovative approach to teach environmental education along with Kamishibai card' (b) Design and build the kamishibai card and hologram multimedia for teaching Environmental Education in Indonesia.

\section{Literature Review}

\subsection{Kamishibai}

Kamishibai is a method of storytelling using images. Images that represent the story are painted on pieces of paper. Both sides of the report are used in such a way as to help facilitate the delivery of the information. [9] suggested that the article's front side was painted with colored pictures to show the audience. Simultaneously, the article's backside is written with words to make it easy for the singer to tell the story.

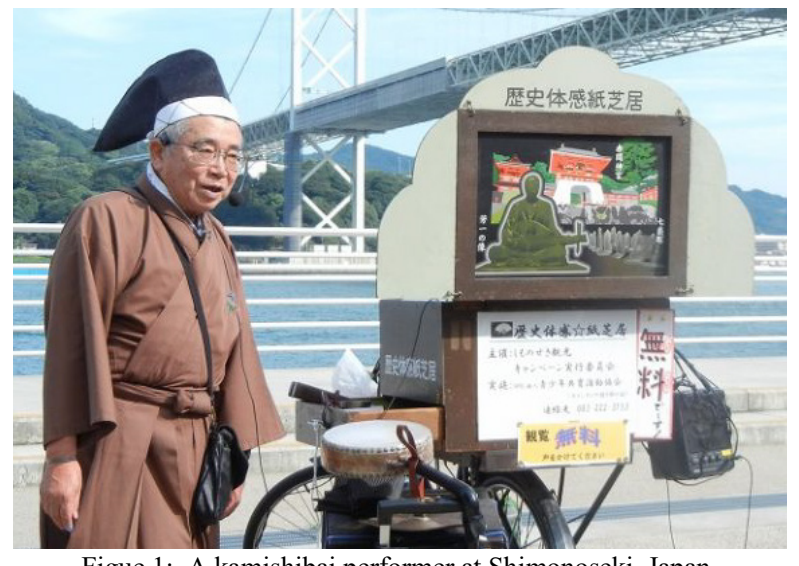

Figue 1: A kamishibai performer at Shimonoseki, Japan

(Source: https://www.shimonoseki.travel/news/?newsid=434\&cates=3)

According to [10], Kamishibai is almost the same as a presentation, but a presentation usually uses power points as supporting media. The Kamishibai method has several advantages, which can help students increase self-confidence when appearing in front of people and as a learning medium for writing. Besides being able to train students' cognitive skills, the kamishibai method can also make students think creatively.

In [11], there is a publishing company that publishes Kamishibai teaching materials used by teachers in schools. Using this kamishibai teaching material, the teacher can explain the material to be taught in a fun way by telling stories. Therefore, researchers researched the effectiveness of the Kamishibai method in environmental education learning.

In some studies, the kamishibai method is suitable for adaptation in learning. Because this Kamishibai method does not only offer verbal potential. However, many other possibilities can be extracted from the Kamishibai method, such as writing and drawing. This can have a significant impact on learning.

In [12], the author said kamishibai could also help students find symptoms and causes of environmental problems by emphasizing environmental problems' complexity, thereby encouraging critical thinking and problem-solving skills. Students can also utilize a variety of learning environments and approaches 
in learning environments with an emphasis on changing students' mindsets.

\subsection{Hologram for Educational Multimedia}

Research on the methods of displaying 3D objects has been carried out in recent years. There are two techniques for displaying 3D objects, namely stereoscopic and autostereoscopic. Autostereoscopic 3D Display methods use projection techniques such as a volumetric display [13] or by using $3 \mathrm{D}$ architecture and artificially generated displays [14], [15] for displaying 3D objects. Volumetric displays of strings and projectors that project objects on artificially generated displays such as fog displays and water droplet displays were also developed. At least one projector is needed to project a 3D floating object and the observer cannot reach their hands to the $3 \mathrm{D}$ object because there is an artificial screen around the object and the object will disappear when the hands interact with it.

Another more straightforward method for displaying 3D objects without glasses is the concept of pepper ghost using an oblique plane reflector made of acrylic, as shown in Figure X, developed by the previous team [16]. Four symmetrical variations of opposite objects on the LCD screen are projected on the pyramid's four faces, and we adopted from [17]. Through this projection, each side of the object falls in the middle of the pyramid. Figure 2 shows the design of the holographic reflector system on one side.

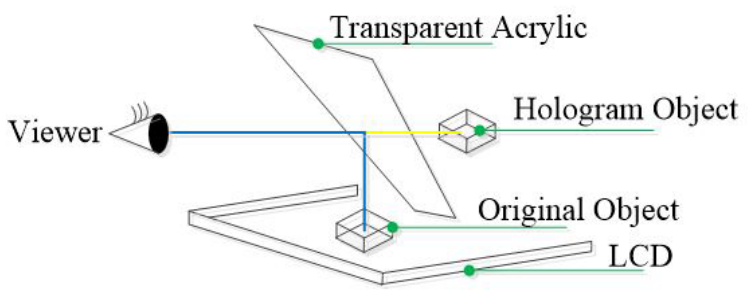

Figure 2: The concept of hologram reflection[16]

Four symmetrical variations of opposite objects on the LCD screen are projected on the pyramid's four faces. Through this projection, each side of the item falls in the middle of the pyramid. Figure 3 shows the design of a pyramid holographic reflector system.

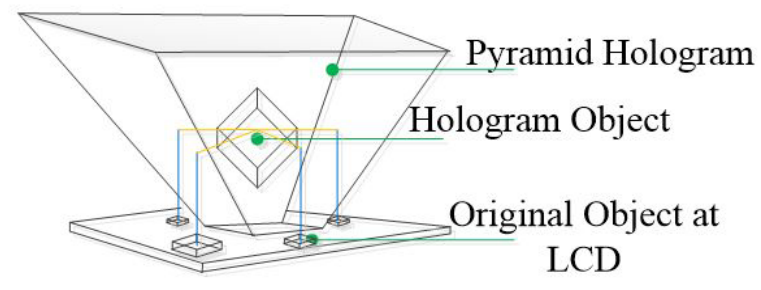

Figure 3: Build a 3D image object from 4 2D images[16]

\subsection{Environmental Education in Indonesia}

Environmental Education is one of the efforts in instilling an attitude of environmental love. In UU no. 32 Year, 2009 Republik Indonesia concerning environmental protection and management, it has been stated that the environment is defined as a unitary space that includes all objects, power, and living conditions, including humans and their behavior that affect the environment, the sustainability of life, and the welfare of humans and other creatures. Environmental education certainly has a particular vision, namely the realization of Indonesian people who have the knowledge, awareness, and skills to play an active role in preserving and improving the environment's quality; this vision was conduct with [18]. Based on this vision, of course, environmental education is taught as early as possible to children, including children aged 7-12 years in elementary school [19].

According to development and basic concepts of environmental education[20], the implementation of environmental education learning in schools has several obstacles, including the methods and materials used which are not yet sufficient so that students' understanding is incomplete [21]. Therefore, in the delivery and learning process, there need to be exciting innovations. Of course, it is connected with daily life so that the learning process becomes more meaningful while answering existing environmental problems.

At the Elementary School level of education, the environmental education material already in the Environmental Education subject has been integrated with other topics such as Indonesian Language and Natural Sciences. This is done because integrated learning can foster students' thinking skills. Following the child's needs, learning becomes more meaningful so that learning outcomes will last longer than learning separately.

One of the environmental education materials in grade 5 Elementary School in theme 2, Clean Air for Health in sub-theme 3 , discusses maintaining human respiratory organs. This material was chosen because from 2018 to the present, upper respiratory tract disease occupies the first position in the condition most experienced by Bandung residents. The material teaches children how to prevent respiratory illness through clean and healthy living habits and maintain human respiratory organs.

\section{Research Method}

The research method is used as a plan for how a study is carried out. To answer all the research problem formulations, a Research \& Development (R\&D) research or research methodology is often called. Research and development methods are research methods used to produce specific products and test their effectiveness [22]. The research will be carried out for 12 working months, from the preparation stage to the reporting stage. The research will be conducted in two countries, Indonesia and Japan. The data from Japan will be the basis of the development while it is modified to Indonesian's curriculum. The designing stage of kamishibai and hologram content firstly will be taken place in Japan. Further development site is carried out at UPI Bumi Siliwangi and UPI Cibiru Campus. The experimentation research on kamishibai and hologram usage will take place in two elementary schools in Bandung.

This research will be done with an $\mathrm{R} \& \mathrm{D}$ procedure; however, some addition and grouping make it as seen in the figure below.

- Analysis and data collection

The research started by study the Indonesian curriculum on environmental education. The context is enlisted and explored. The most suitable topic will be selected as an example of the content of Kamishibai and hologram multimedia. The system requirement analysis is also done in this step to prepare the development of hologram multimedia. 


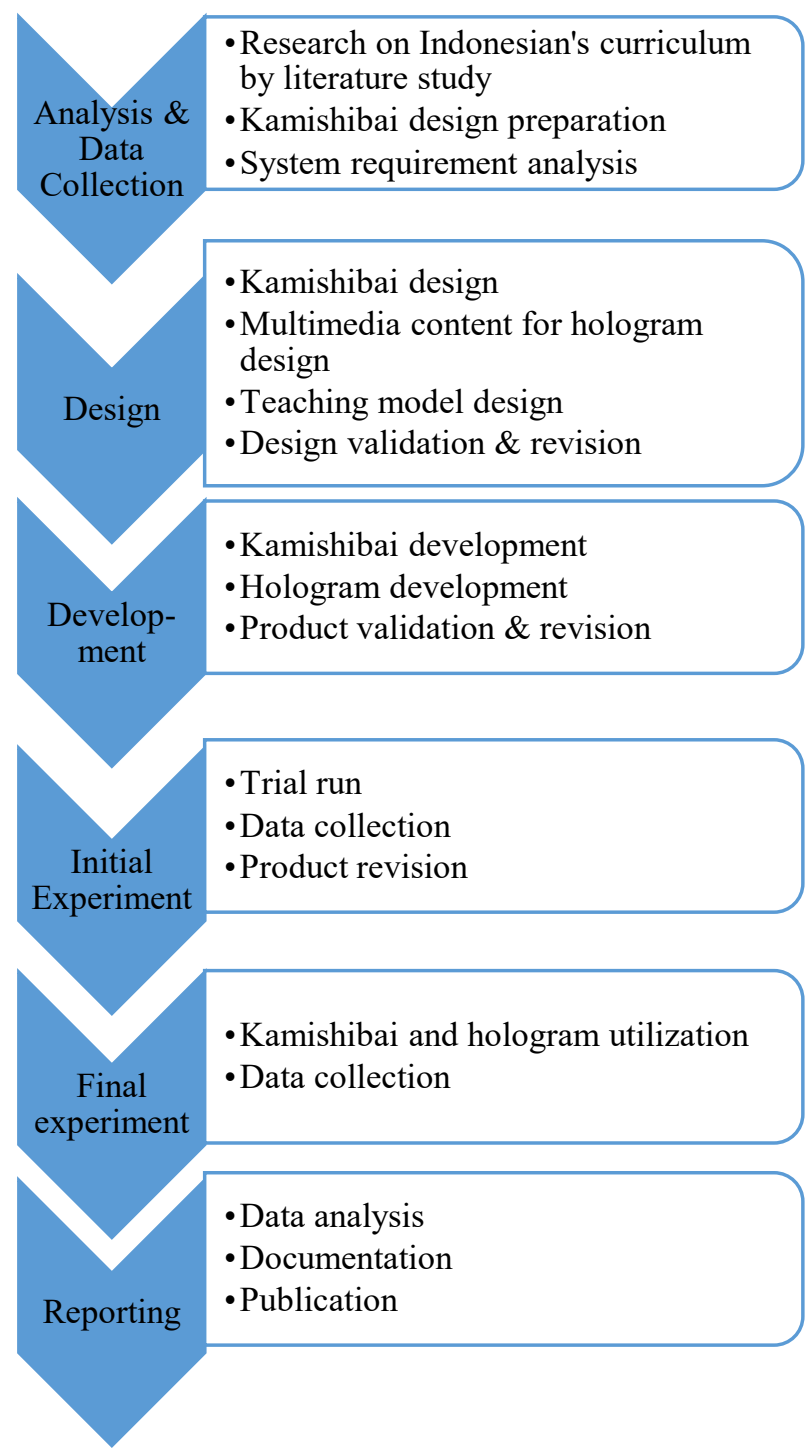

Figure 4: Research Design

- Design

The kamishibai card and the hologram multimedia should have a meaningful story that is explained through some pictures. Based on the analysis and data collection from the previous step, the content and storyboard are designed. Along with kamishibai and hologram multimedia, the teaching model was also developed in this step. Finally, the result of this step should be validated by the expert.

- Development

At this step, all of the teaching media is created.

Kamishibai's prototype should be printed, and the

hologram with its content should be finished to develop at this step. Those products then should be validated by the expert again. After the validation and revision, the production of the kamishibai card then should be finished.

- Initial experiment

The first trial run is done at a smaller sample of research. At this point, the sample might is not the elementary school student but the student at university. After the trial run, the product revision will be done according to the trial run's foundation and data collection.

- Final experiment

The final trial run is taken place at the elementary school. The real sample is observed, and the research data is also collected in this step

- Reporting

The last step of this research is reporting. The research data is analyzed and documented. Finally, the result should be published.

The research instrument in the form of a questionnaire and test are used in this study. This questionnaire aims to get feedback and opinions from the research subject and the expert in terms of user satisfaction and multimedia learning effectiveness. Pre-test and post-test also are delivered in this research to analyze the student's ability improvement.

The study was conducted with research subjects divided into two groups, namely students and expert teams. The expert team is an expert in the field of multimedia and education. In this study, the expert is some selected lecturer from the University of Kitakyushu and UPI. The subjects of the study are elementary school students. For sample selection done randomly or by random area sampling. In [23], the author suggests that in quasiexperimental research, researchers can use existing classes and make one class as an experimental class and another class as a control class. The selection of regions for the sample and control of each of the three schools in the different areas. And each student for the control class and model has equal abilities so that they meet the matching element requirements according to the method approach used.

\section{Result and Discussion}

\subsection{Explore the potential of hologram multimedia as an innovative approach to teach environmental education along with the Kamishibai card}

The development of multimedia holograms has been carried out in stages by paying attention to the advantages and conveniences for students who use them. Of course, the same is true for the teachers, where they have to be ready and master what and how this multimedia hologram is, considering that teachers must first master the characteristics of this multimedia hologram which is at the same time how to package environmental education content that they will present to their students. As the research team described in the literary study, visually, this multimedia hologram's design can be seen in the image below.

The kamishibai Hologram product model has been developed from this research, starting from the product engineering development stage, as shown in the picture below.

From the Multimedia Hologram, there are stages of prototype development that must be considered by both the developer and the teacher who will be the user. For example, this prototype's use must be avoided from the instability of the electric current, considering that if it is unstable, it will cause the effect of the holographic object that appears to be weak [24]. This fig. 6 construction will produce a light replicator effect that will display three-dimensional objects [25] as objects presented and seen on 
the television screen in front of them. This process allows this hologram-shaped object to attract users who observe it.

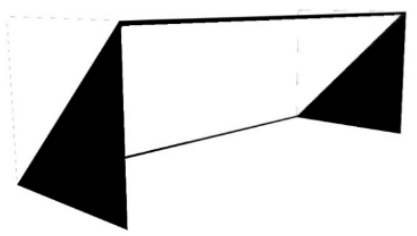

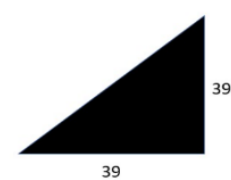

39
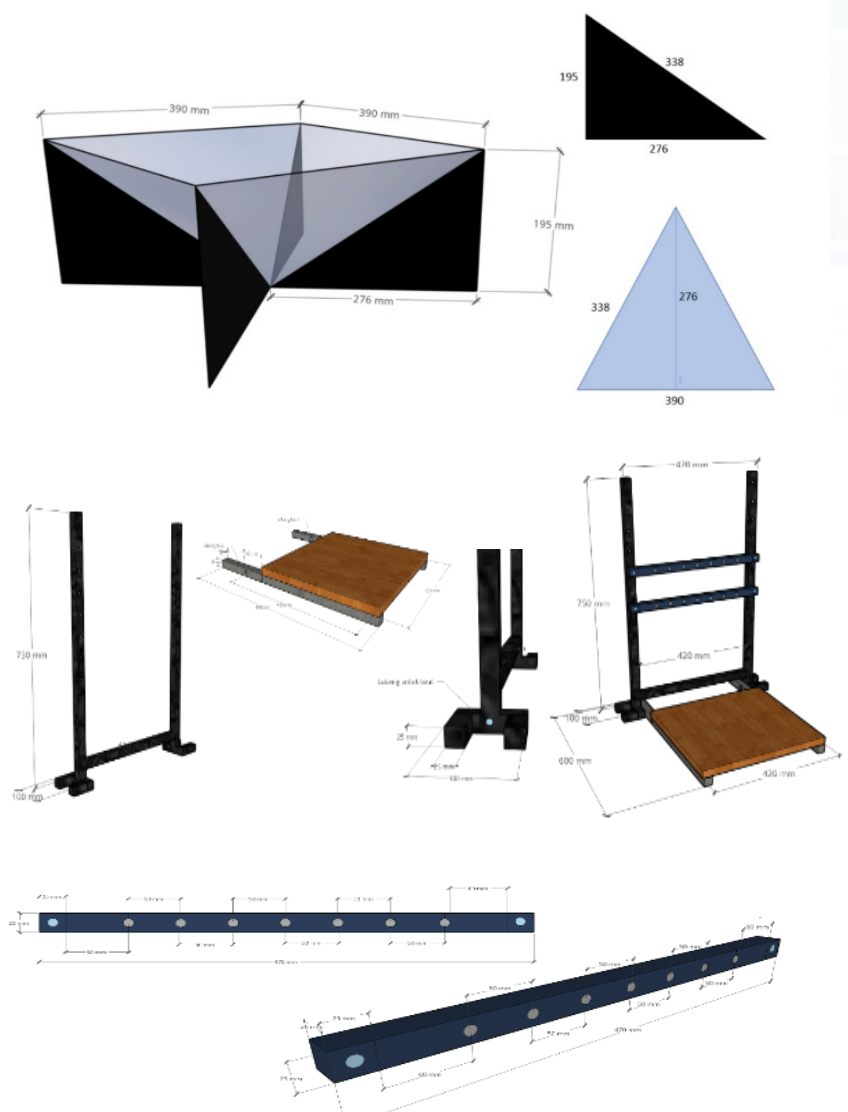

Figure 5: Multimedia Hologram Production Equipment and Materials

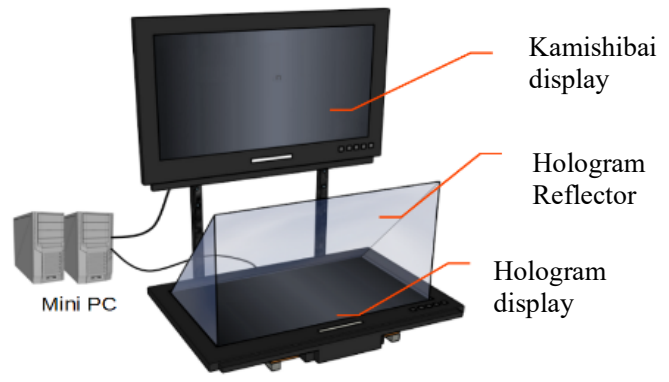

Figure 6: Final Product of Hologram Multimedia Kamishibai

\subsection{Design and build the hologram multimedia and kamishibai} card for teaching Environmental Education in Indonesia

Kamishibai card design and development are integrated and presented through the effect of a hologram containing environmental education material. The theme of environmental education is made in pictorial stories whose content is related to students' world at the age of elementary education, which was conduct from [26]. The results of the developments that have been carried out can be seen in the following.
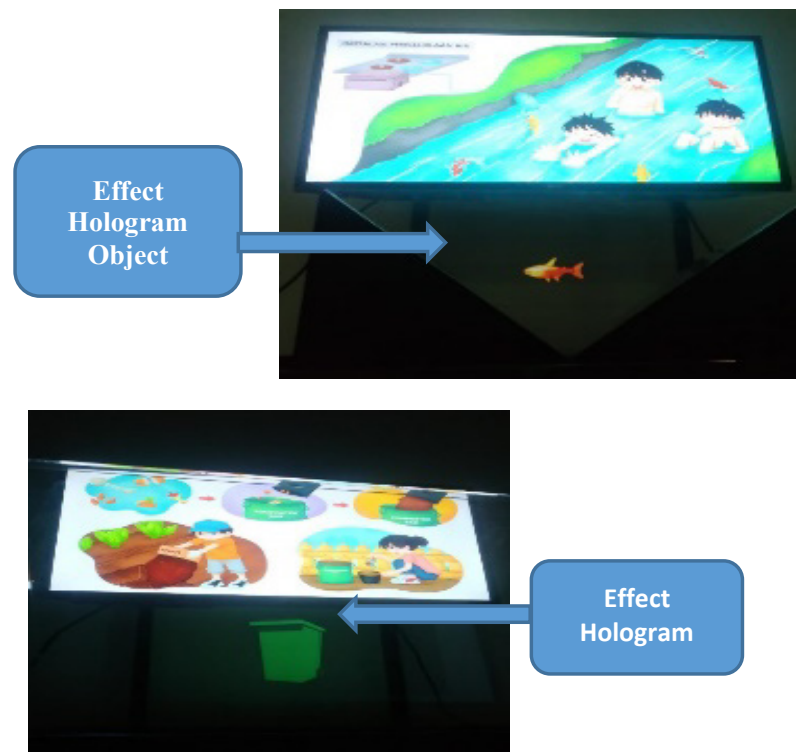

Figure 7: Sample of the content of environmental Education Through Effect Hologram on "Fish Story and Garbage Story"

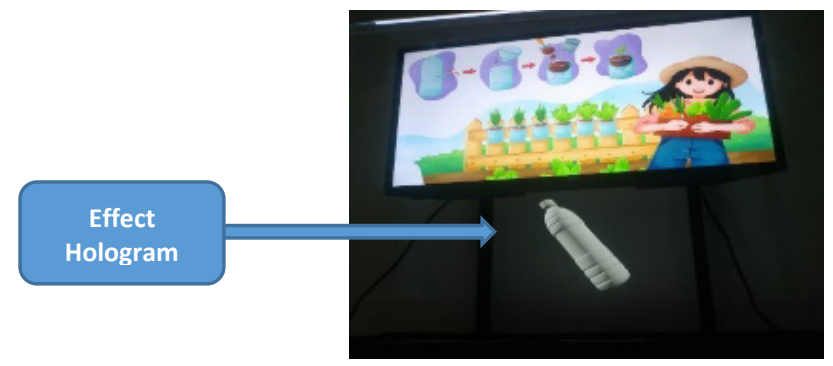

Figure 8: Sample of the content of environmental Education Through Effect Hologram on "Utilization of Plastic Bottle Garbage"

From the analysis of environmental education content and policies, various points of view can be described to strengthen the development efforts that can be equated through the Kamishibai and Hologram models as formulated in this study[27]. The study of the environment is a spatial unity with all objects, forces, conditions, and living things, including humans and their behavior, which affect nature itself, the continuity of life, and humans and other living creatures' welfare. That is the definition of the environment as in Law No. 32 of 2009 concerning Protection and Management of the Environment. Final Garbage Disposal Place, or TPA,[28]. Garbage is a place to quarantine garbage or pile up garbage transported from a waste source to disturb the environment. This must be the primary target of students' knowledge and attitudes towards environmental learning 
materials. The research shows that students' attitudes change after taking lessons with the kamishibai and hologram models they see.

In the notebook, in 1986, environmental and population education was included informal education with the formation of the subject? Population and environmental education (PKLH) ?. The Ministry of Education and Culture felt the need to start integrating PKLH into all subjects at the primary and secondary education levels (general and vocational secondary), the delivery of topics on population and environmental issues in an integrated manner as outlined in the 1984 curriculum system by incorporating population and ecological problems lives into almost any subject. Since 1989/1990 until now, various training pieces on the environment have been introduced by the Ministry of National Education for elementary, junior high, and high school teachers, including vocational schools.

A joint memorandum was issued between the Ministry of Education and Culture and the Office of the State Minister for the Environment No. 0142 / U / 1996 and Kep No: 89 / MENLH / 5/1996 concerning Guidance and Development of Environmental Education, dated 21 May 1996,[29]. In line with that, the Directorate General of Primary and Secondary Education, Ministry of Education and Culture, also encourages the development and consolidation of implementation. Environmental education in schools, among others, through teacher upgrading, encouraging environmental service months, preparation of Population and Environmental Education Implementation Guidelines (PEEIG) for elementary, junior high, high school, vocational school teachers, and beautiful school programs, and others. Meanwhile, NGOs and higher education institutions develop environmental education through seminars, workshops, teacher upgrading, educational facilities such as the preparation of integration modules, reading books, etc.

On 5 July 2005, the Minister of Environment and the Minister of National Education issued joint decree number: Kep No 07 / MenLH / 06/2005 No 05 / VI / KB / 2005, [30] for the guidance and development of environmental education. This joint decision strongly emphasizes that ecological knowledge is carried out in an integrated manner with existing subjects. Environmental Education (EE) is a process to build a human population in the world who is aware of and cares about the total environment (as a whole) and all the problems associated with it, and people who have knowledge, skills, attitudes, and behavior, motivation and commitment to work together, both individually and collectively, to be able to solve various current environmental problems, and prevent new problems from arising[31].

In the context of this research, the meaning of EE or the environment, as described above, basically wants to be seen from the aspect of its sustainability. So that in this context, the understanding of Environmental Sustainability Education according to [32] is explained as:" sustainable development is about integration: developing in a way that benefits the most comprehensive possible range of sectors, across borders and even between generations. In other order words, our decisions should take into consideration potential impact on society, the environment, and the economy, while keeping in mind that: our actions will have implications elsewhere and our efforts will affect the future."
Environmental issues are systemic, complex, and have a broad scope. Therefore, the material or issues raised in the implementation of environmental education activities are also very diverse. Following the national agreement on Sustainable Development stipulated in the Indonesian Summit on Sustainable Development (ISSD) in Yogyakarta on 21 January 2004, 3 (three) pillars of sustainable development have been established: economic, social, and environmental.

The three pillars form a unity that is interdependent and mutually reinforcing. The core of each post is:

a) Economic Pillar emphasizes changes in the economic system to make it more environmentally friendly following sustainable development principles. Related issues or materials are: consumption and production patterns, clean technology, funding/financing, business partnerships, agriculture, forestry, fisheries, mining, industry, and trade

b) Social Pillar emphasizes community empowerment efforts in environmental conservation efforts. Related issues or materials are Poverty, Health, Education, local wisdom/culture, rural communities, urban communities, isolated / remote communities, good governance/institutions, and law and supervision.

c) The environmental pillar emphasizes the sustainable management of natural resources and the environment. Related issues or materials are water resources management, land resources management, control of air resources, management of marine and coastal resources, energy and mineral resources, conservation of rare animals/plants, biodiversity, and spatial planning.

The team has developed environmental education content used as learning material with the Conventional Kamshibai Models, which will then be projected from the research results. Furthermore, the content development of Kamishibai Hologram Multimedia is carried out; as previously explained, Kamiholo content consists of assets, including kamishibai scenes in the form of 2D images and background sounds. The storyline and content series displayed on the Kamishibai Hologram Multimedia system is as follows.

From the results of the development of the Kamishibai Hologram Multimedia model, several indicators have been found to strengthen the learning of PLH at the elementary school level. A number of these reinforcers include (1) Learning Process; (2) student motivation; (3) PLH Material Content; (4) Multimedia Aspects; and (5) Usage Constraints; and (6) Technology. As for the design results of the development of the Conventional Kamishibai (Cards) model in the form of Cards (Kamishibai Cards), it can be found several influences on the learning process of Environmental Education in Elementary Schools. A number of these indicators include (1) Learning Process; (2) student motivation; (3) PLH Material Content; (4) Media Aspects; and (5) Usage Constraints. The findings of each of these indicators are an explanation of the opinion of the previous research results on environmental learning research, including according to[12], [17], [31], [33]. 
Table 1: Develop Content of Kamishibai Hologram Multimedia

\begin{tabular}{|c|c|c|c|c|}
\hline $\begin{array}{l}\text { No. } \\
\text { Scene }\end{array}$ & Kamishibai Image & 3D image & $\begin{array}{l}\text { Back } \\
\text { sound }\end{array}$ & Story \\
\hline 1 & & N/A & $\begin{array}{l}\text { Music } \\
\text { with a } \\
\text { cheerful } \\
\text { tone. }\end{array}$ & $\begin{array}{l}\text { In the opening scene, the teacher provides an } \\
\text { initial description of the material to be } \\
\text { delivered. }\end{array}$ \\
\hline 2 & & $\begin{array}{l}\text { Animated } \\
\text { Fish }\end{array}$ & $\begin{array}{l}\text { The } \\
\text { sound of } \\
\text { water } \\
\text { gurgling }\end{array}$ & $\begin{array}{l}\text { Near my house, there is a prominent river. } \\
\text { Lots of fish and plants. } \\
\text { I love to play by the river } \\
\text { The air is fresh, too; I love the sound of the } \\
\text { river water splashing. } \\
\text { The teacher interacts with students about the } \\
\text { types of fish displayed or fish that have been } \\
\text { seen in the river. }\end{array}$ \\
\hline 3 & & $\begin{array}{l}\text { Garbage } \\
\text { bags }\end{array}$ & $\begin{array}{l}\text { Staccato } \\
\text { music } \\
\text { with a } \\
\text { sneaky } \\
\text { impressi } \\
\text { on }\end{array}$ & $\begin{array}{l}\text { However, some people throw their garbage into } \\
\text { the river so that the river becomes dirty, and a } \\
\text { lot of waste piles up in the river body }\end{array}$ \\
\hline 4 & & $\begin{array}{l}\text { Paper } \\
\text { Garbage }\end{array}$ & $\begin{array}{l}\text { The } \\
\text { sound of } \\
\text { water } \\
\text { and panic } \\
\text { music }\end{array}$ & $\begin{array}{l}\text { The river became dirty. Lots of trash on the } \\
\text { riverbank. Lots of plastic waste on the } \\
\text { riverbank. The river water becomes } \\
\text { contaminated and cloudy. When it rains, the } \\
\text { water overflows, and there is a flood. }\end{array}$ \\
\hline 5 & & $\begin{array}{l}\text { Types of } \\
\text { Garbage: } \\
\text { - Paper } \\
\text { - Plastic } \\
\text { bottle } \\
\text { - Cans }\end{array}$ & $\begin{array}{l}\text { Upbeat } \\
\text { music }\end{array}$ & $\begin{array}{l}\text { Fortunately, some children are already learning } \\
\text { about environmental education. They clean the } \\
\text { river. They pick up trash. Invite parents, } \\
\text { neighbors, and friends to throw garbage into the } \\
\text { river and make the environment clean and } \\
\text { healthy. These children already understand the } \\
\text { importance of environmental clean liness. } \\
\text { Teachers can deliver material about organic and } \\
\text { inorganic waste. }\end{array}$ \\
\hline 6 & & $\begin{array}{l}\text { Examples } \\
\text { of trash: } \\
\text { Cardboard } \\
\text { Leftovers } \\
\text { Glass bottle } \\
\text { The plastic } \\
\text { toy is } \\
\text { broken } \\
\end{array}$ & $\begin{array}{l}\text { Music } \\
\text { with an } \\
\text { uplifting } \\
\text { tone. }\end{array}$ & $\begin{array}{l}\text { They sort trash. Organic waste is used as } \\
\text { organic fertilizer. Inorganic waste is taken to } \\
\text { the garbage bank. So that their home } \\
\text { environment looks clean and the air becomes } \\
\text { fresh. } \\
\text { The teacher reconfirms the material presented } \\
\text { on the previous slide with a 3D image stimulus. }\end{array}$ \\
\hline 7 & & $\begin{array}{l}\text { Vegetable } \\
\text { waste and } \\
\text { bone waste }\end{array}$ & $\begin{array}{l}\text { Music } \\
\text { with an } \\
\text { uplifting } \\
\text { tone }\end{array}$ & $\begin{array}{l}\text { Garbage that comes from } \\
\text { A home kitchen can be used as organic } \\
\text { compost to fertilize plants in your home to } \\
\text { make it healthier. }\end{array}$ \\
\hline
\end{tabular}




\begin{tabular}{|c|c|c|c|c|}
\hline 8 & & PET bottles & $\begin{array}{l}\text { Music } \\
\text { with } \\
\text { inspiratio } \\
\text { nal tones }\end{array}$ & $\begin{array}{l}\text { We can grow crops, with healthy vegetables or } \\
\text { flowers. We are planting vegetables in bottled } \\
\text { pet media. We can use plastic bottles as a } \\
\text { medium. Do you have plastic bottles in your } \\
\text { house? }\end{array}$ \\
\hline 9 & & Wastewater & $\begin{array}{l}\text { Music } \\
\text { with } \\
\text { inspiratio } \\
\text { nal tones }\end{array}$ & $\begin{array}{l}\text { Likewise with dirty water from home. Used } \\
\text { bathroom water, } \\
\text { Water from washing dishes, water from } \\
\text { washing clothes. These are referred to as } \\
\text { household wastewater. Let's filter it out in the } \\
\text { water management plant } \\
\text { And throw it into the river. }\end{array}$ \\
\hline 10 & & N/A & $\begin{array}{l}\text { Music } \\
\text { with } \\
\text { impressi } \\
\text { ons } \\
\text { provokes } \\
\text { thought. }\end{array}$ & $\begin{array}{l}\text { Then, what do you think? } \\
\text { If all the people in your city keep the river } \\
\text { clean, } \\
\text { Do not throw garbage into river bodies, and do } \\
\text { not dispose of wastewater into rivers. What do } \\
\text { you think? } \\
\text { The teacher concludes the material that has } \\
\text { been delivered. }\end{array}$ \\
\hline 11 & & N/A & $\begin{array}{l}\text { Music } \\
\text { with } \\
\text { inspiratio } \\
\text { nal tones. }\end{array}$ & $\begin{array}{l}\text { What can we do? } \\
\text { So that our rivers will be clean? } \\
\text { The teacher opens discussions and reflects on } \\
\text { the material with students. }\end{array}$ \\
\hline
\end{tabular}

\section{Conclusion and Recommendation}

Exploring the potential of multimedia holograms as an innovative approach to teaching environmental education and Kamishibai cards has been systematically formulated in this study. The multimedia development approach is directed at supporting multimedia resources. Students are more attracted when they know the various types of waste in the environment that can be used or recycled. Of course, through the multimedia hologram found in this study, students have determined the garbage classification only for recycling. Likewise, with the trash around the river, with this multimedia hologram media design, students have been able to identify it too because they have clearly shown the effect of an authentic hologram.

Designing and building kamishibai cards and multimedia holograms for learning Environmental Education in Indonesia have been shown from the research results in the form of a series of storyboards in pairs between descriptions and serial picture cards as kamishibai cards. These findings have been formulated in lesson plans regarding a series of explanations about students' care and ability to demonstrate literacy, knowledge, attitudes, and psychomotor, which are facilitated when making decisions about caring for the surrounding environment. Through this research, students are aware that they will maintain the balance of nature and the environment's cleanliness, which they show through their real knowledge, attitudes, and activities. Thus, this change has been demonstrated to show the multimedia hologram prototype's strength, providing concrete messages about all environmental education content at the basic education level.

\section{Conflict of Interest}

The authors declare no conflict of interest

\section{Acknowledgments}

This work was supported by a grant from the Decree of the Chancellor of the University of Education of Indonesia Number: 704 /UN40.D/PT/2020, 26 June 2020 Regarding Grant Recipients for Research and Community Service Programs for the 2020 Fiscal Year.

\section{References}

[1] Rachman, PBL ( Problem-based Learning ) Method by using "Kamishibai " as a Media To Learn Environmental Education For Children And To Build Capacity For Teachers Indriyani Rachman, Toru Matsumoto , Yayoi Kodama , and Hiroyuki Miyake Abstract Keyword : History of, 2017, 1(1), $55-60$. 
[2] N. Sibley, R. Krause, Kamishibai, Japanese Storytelling: The Return of An Imaginative Art, 39-41, 1995.

[3] D. Las Casas, Kamishibai story theater: The art of picture telling, 2006. 2006.

[4] F. Ramadhani, Using Kamishibai In Teaching Speaking For Junior High, 2014,(March).

[5] T. M. McGowan, Kamishibai story theater: The art of picture telling, 2010. 2010.

[6] M. Ngafifi, Kemajuan Teknologi Dan Pola Hidup Manusia Dalam Perspektif Sosial Budaya, Jurnal Pembangunan Pendidikan: Fondasi dan Aplikasi, 2014, 2(1), 33-47.

[7] V. Siang, Interactive Holographic Application using Augmented Reality EduCard and 3D Holographic Pyramid for Interactive and Immersive Learning, 2017 IEEE Conference on e-Learning, e-Management and eServices (IC3e), 2017, 73-78. DOI: 10.1109/IC3e.2017.8409241

[8] I. Tawaqqal, I. P. Ningrum, M. Yamin, Hologram holographic pyramid 3 dimensi, 2017, 3(1), 181-188.

[9] D. Darmawan, A. Kiyindou, C. Pascal, ICMLS version 3.0 as a prototype of bio-communication model for revolutionary human numerical competences on vocational education practices, Journal of Physics: Conference Series, 2019, 1402(7), 0-7. doi: 10.1088/17426596/1402/7/077073/meta

[10] P. O. McGowan et al., Epigenetic regulation of the glucocorticoid receptor in human brain associates with childhood abuse, Nature Neuroscience, 2009, 12(3), 342-348

[11] T. Matsui, T. Nomura, K. Yagyu, Flavor Dependent \$U(1)\$ Symmetric Zee Model with a Vector-like Lepton, 2021.

[12] N. A. Rahman, L. Halim, A. R. Ahmad, T. Mastura, T. Soh, Challenges of Environmental Education: Inculcating Behavioural Changes among Indigenous Students, 2018, 43-55.

[13] D. Miyazaki, N. Hirano, Y. Maeda, S. Yamamoto, Floating volumetric image formation using a dihedral corner reflector array device, Applied Optics, 2013,(October 2014).

[14] I. Suzuki, A. Ishii, Y. Ochiai, Gushed light field : design method for aerosolbased fog display Gushed Light Field: Design Method for Aerosol-based Fog Display, https://www.researchgate.net/publication/311097762_ Gushed light field design method for aerosol-based fog display? enrichI $\overline{\mathrm{d}}=$ rgreq-563e $4472 \mathrm{e} 3853 \mathrm{a} 353 \mathrm{~d} 025775 \mathrm{da} 8408 \mathrm{f} 7-\mathrm{XXX}$ X \&enrich Source=Y292ZXJQYWdlOzMxMTA5Nzc2MjtBUzo1Njc3NTExNTQ4M zEzNjBAMTUxMjM3MzgzMTM1Nw\%3D\%3D, 2016,(November), 4-6.

[15] T. Barnum, P. C., Narasimhan, S. G., \& Kanade, A multi-layered display with water drops., In ACM Transactions on Graphics (TOG), 2010, 29(4), 76. doi: $10.1145 / 1833349.1778813$

[16] J. Mahfud, T. Matsumaru, Interactive aerial projection of 3D hologram object, 2016 IEEE International Conference on Robotics and Biomimetics, ROBIO 2016, 2016, 1930-1935.

[17] A. K. A. Grobelak, M. K. K. A. Lyng, Methods and tools for environmental technologies risk evaluation: the principal guidelines - a review, International Journal of Environmental Science and Technology, 2020,(Denmark 2011)

[18] M. J. Stern, R. B. Powell, D. Hill, M. J. Stern, R. B. Powell, D. Hill, Environmental education program evaluation in the new millennium : what do we measure and what have we learned?, Environmental Education Research, 2014, 4622, 1-31.

[19] H. Lateh, P. Muniandy, Pre-Service Teachers ' Attitude towards Teaching Environmental Education ( EE ) during Practicum in Malaysian Primary Schools, 2013, 2013(February), 201-204.

[20] J. C. Gill, J. Mankelow, K. Mills, The role of Earth and environmental science in addressing sustainable development priorities in Eastern Africa, Environmental Development, 2019, 30(August 2018), 3-20.

[21] N. A. Rahman, N. M. Nasri, Environmental Literacy: Indigenizing Environmental Education, 2018, 2148-2160.

[22] M. D. Borg, Walter R, and Gall, Educational Research, London: Longman., 1998 ,.

[23] J. W. Creswell, Research Design: Qualitative and Quantitative Approach,., California: Sage Publication., 2015,

[24] Y. Maeda, D. Miyazaki, T. Mukai, S. Maekawa, Volumetric display using rotating prism sheets arranged in a symmetrical configuration, 2013, 21(22), 279-284. doi: $10.1145 / 1833349.1778813$

[25] T. Ohara, K. Sakamoto, S. Nomura, Stereoscopic 3D Display System Using Commercial DIY Goods, International Association of Engineers, 2009, I(Lcd).

[26] D. Saheb, D. G. Rodrigues, M. Celia, C. Guebert, The Environmental Education in Teachers ' Initial Training of and the Seven Complex Lessons of Morin : Contributions and Challenges, 2017, 447-460, 2017.
[27] M. S. S. Abu BakarAbdullahMuhammada, Nor Anita Fairos Ismaila, Reflective Prism Display Using Pepper's Ghost Technique Software Toolkit Plugin For Unity 3d., Jurnal Teknologi, 2016, 3, 189-196.

[28] Minister of Environment., Law No. 32 of 2009 concerning Protection and Management of the Environment. Final Waste Disposal Place or TPA, Jakarta: Minister of Environment. Republik Indonesia, 2009,

[29] J. M. between the M. of E. and C. and the O. of the S. M. for the E. N. 0142 / U. / 1996 and K. N. 89 / MENLH, Concerning Guidance and Development of Environmental Education, Ministry of Education and Culture and the Office of the State Minister for the Environment, 1996,

[30] M. of E. and M. of N. Education., Regarding the Joint Decree number: Kep No 07 / MenLH / 06/2005 No 05 / VI / KB / 2005., Jakarta: Minister of Environment and Minister of National Education of the Republic of Indonesia, 2005,

[31] C. Leandro et al., Environmental Education in Micro and Small Enterprises : Innovation for Sustainability, Creative Education, 2019, 922-939.

[32] A. Strange, T. and Bayley, OECD Insights Sustainable Development Linking Economy, Society, Environment., OECD Report, Geneva., 2008,

[33] A. Georgopoulos, M. Birbili, A. Dimitriou, Environmental Education ( EE ) and Experiential Education: A Promising " Marriage " for Greek PreSchool Teachers, 2011, 2(2), 114-120. 